\section{Transformations Arcing Over Changes of Regimes in the History of a University Department}

\section{Laszlo Brezsnyanszky ${ }^{1}$}

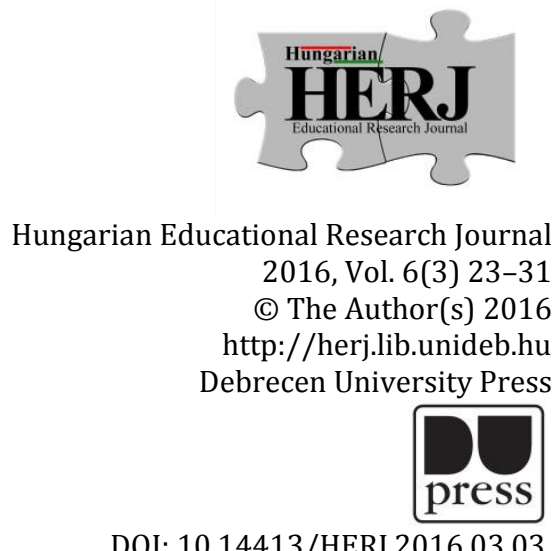

DOI: 10.14413/HERJ.2016.03.03.

\begin{abstract}
Our research aims to explore what transformations happened in the academic world of Pedagogy during the sixty years (1912-1970) marked with many changes. We analysed the manifestations of the personal, structural and professional continuity and discontinuity of the professorship of the history of the department of Pedagogy of a university. During the research we worked with the academic documents and sources of the archives. We were able to lean upon the accounts and reminiscences of witnesses of the period who are still alive today. Sacred to the memory of Professor Mitter, we would like to enrich the repertoire of the researches of sociological transformations with an instance of an institutional history.
\end{abstract}

Keywords: university history, professorship of Pedagogy, transformation period of the 20th century, continuity and discontinuity

\footnotetext{
${ }^{1}$ Professor Emeritus, University of Debrecen, Institute of Educational Studies, Hungary. Email address: brezsnyanszky.laszlo@arts.unideb.hu

Recommended citation format: Brezsnyanszky, L. (2016). Transformations Arcing Over Changes of Regimes in the History of a University Department. Hungarian Educational Research Journal, 6(3), 23-31, DOI: 10.14413/HERJ.2016.03.03.
} 


\section{Introduction}

The following study is a tribute to the memory of Professor Wolfgang Mitter. I had the privilege of meeting him multiple times throughout my career, back in the days of the split Germany in Frankfurt and later on, in other places in different professional workshops. He was our guest speaker at the University of Debrecen on more occasions. He was travelling through many countries with his presentations; he was known as the ambassador of the comparative Pedagogy. In my opinion he was really at home in the Middle-European area and this world was really familiar in his soul and habit and he was its true representative.

He was one of the guests of honour in the National Pedagogical Conference in 2003 in Budapest. On the opening day, he had a presentation on the relationships between the education politics and the change of the regime in the state room of the Hungarian Academy of Science. On the basis of the union of two German states he pointed out some features and problems. The text of the presentation was published in the following issue of Hungarian Pedagogy (Magyar Pedagogia) 2003. Issue no. 4 (Mitter, 2003)

Having read his presentation again ten years later, I think it is worth reminiscing his claims and reflect them with respect and looking for the experiences actual for our own research endeavours.

"The notion of transformation - according to Mitter - can already be found in the special literature of sociological science of the 30's of the 20th century, however, it was widely spread in the last tertiary of the century to express the political and social changes taking place in the Middle and East Europe" (Mitter, 2003:413).

In this regard, transformation means the social and political changes of regime which were many during the last hundred years in this area of Europe; the kind of changes which 'upset the world' fundamentally and permanently.

Professor Mitter chose to analyse the change of regime and union of the German Democratic Republic. The very transformation that was earlier seemingly impossible, bringing joyful alterations not only for German people but for the world politics. He was right in emphasizing: "changes begin in the atmosphere of euphoric anticipation and they extend to the basic and secondary goals as well. Realization is not only characterized by steps towards the goals but by breaks, fragmentations, withdrawals and 'onetime' openly or covertly rebudding attitudes and behaviours that are thought to be excessed long ago" (Mitter, 2003:414).

Shifts - and we can know that from our experiences as well- can be launched among violent or peaceful proportions, they could be swift and fancy, but they get to some consolidation only through a long progress. We are convicted that no matter how successful and futile a transformation is it never happens without distress. However, a 
new chapter is not without a transition either as it wears the marks of continuity in a hidden way. Momenta elevated to symbols of great transformations, such as a cannonshot, breaking of a wall or wire-cutting denote only the momentum of start. Better understanding comes from a thorough and retrospective analyses. It means a serious task for political scientists, researchers of economy and society and historians. Without the chores of historical research the subtle mechanism and its progress of realization of the transformation can hardly be known and understood. Mitter's study warns that researchers regard educational politics as the consequence of the political and economic changes not one of the factors of the transformation. On the other hand, they put the emphasis on the macro processes, they pay less attention to the expectable realizations coming from the micro analyses and biographical researches.

The history of the nations of the Middle-European area of the 20th century abounds in social and political transformations, and the one of the Hungarians was manifested in more complex forms than others. From the 90's, there is a cumulative attention to the investigations of the causes, consequences and connections of transformations. There are more and more publications in researches of education history regarding the period shifts and changes of regime (Nemeth, 2016). At present, the shift happening in the 1940 's and 50's is in the focus. It seems that the change in 1989/90 is too near and the involvement is too real to have objective analyses.

Our research was realised with the support of the following fund: OTKA no. T043016, which was carried out in the spirit of the previously mentioned thoughts to explore the characteristics of the activities of the pedagogical school of the University of Debrecen. It revealed the structural and contextual features of the science-, arts- and teacher training for the period of 1912 and 1970 and before their foundation at the University of Debrecen (Brezsnyanszky, 2007) and as its continuation it still investigated the specialties and composition of today's students as well. It is time for this research to have its sequel and expansion on the basis of raised interest at the centennial of the establishment of the university and the intention of institutions doing scientific research to have their self-determination (Orosz-Barta, 2012; Papp, 2014).

We defined the Pedagogical School of Debrecen as one with three educating functions and activities, mainly parallel - deriving from the features of the universities of the 20th century:

- It took care of the education of the academic second-line of its own professional field, it academically qualified the students held suitable according to the all-time academic certifications.

- It had a training in its own professional discipline and had boarding schools in the field of pedagogy for those students who were interested.

- It maintained the educational tasks of the theoretical pedagogical theory of the teacher training according to the all-time ordinary teacher training. 
In the research we elaborated the rectorial and magisterial documents and archives which concerned the pedagogical training though in this respect not yet revealed. We studied the available materials of teacher training. We were able to lean upon the accounts and reminiscences of witnesses of the period who are still alive today.

Our study summarizes parts of the research which point out the personal, structural and spiritual manifestations of the transformational features of the transitions. Continuity and discontinuity can be observed running along activities of more functions, however, we cannot directly answer where and to what extent we can talk about proven continuity. At the same time, in spite of the sometimes spectacular discontinuity we can neither state that there were more distinct (professorial, academic and professional political) periods following one another for more than half a century. We cannot even state that the periods before and after the war or the shift of the civilian and coalitional regime or that of the socialist, Soviet-style regime could mean global personal and structural discontinuity in the life of the professional field or institutional work.

We can draw an outline on two aspects showing what changes and turning-points were present in the work of the school(s) at the investigated period and where we can look for arcing continuities, maybe furtively predominating. One of the aspects is the continuity of the professorship and the other is the question of professional, theoretical continuity.

\section{The Relative Continuity of the Professorship}

The professorship in this content means the varying named structural unit and first and foremost the status of professorship that meant competence in classes, exams and scientific qualification matters in the division of labour in the university and the faculty of arts.

Taking the first approach, we can say that the University of Debrecen has the continuity in principle for the period of 1918 (the year of foundation) to 1970, therefore the pedagogical unit is marked and working. In fact the work cannot be said continuous completely. There were breaks for personal causes of structural matters. It happened more times that there was no professorship for either a professor could not fulfil the requirements of leadership or because there was not status for a professor. A temporary vacancy in a department was not an unknown phenomenon in the life of the university. For example, in 1922/23 there were only 42 positions hold down out of the 51 authorized departments and 9 of them had deputies (Varga, 1967).

In 1912, at the foundation of the university, pedagogy had no teachers of professorship. Lectures in pedagogy were noticed and given by philosophers. This cooperation; the retraining and training, followed along the educational and qualification activity of the professorship later as well. There were four appointed professors of the department of pedagogy from the foundation until 1970. Gyula Mitrovics (Sarospatak 1871-Stuttgart 
1965) led the department between 1918 and 1941. He was unequivocally the governor of Pedagogy at the university during his professorship. University has to be added as after 1924, with the foundation of the institution of teacher training and its organization alongside the university, the system of teaching Pedagogy has become dual. To our knowledge, there were hardly any maintainers of academic professorship present among the lecturers of the institution of Pedagogy. However, Professors Mitrovics and Karacsony were part of the teachers' examiners committee, so they took part in the quality assurance work. Sandor Karacsony (Foldes 1891-Budapest 1952) was the head of the department between 1942 and 1950. Bela Jausz (Sopron 1895-Budapest 1974) was the head of the department between 1951 and 1966. Laszlo Kelemen (Kiskunfelegyhaza 1919-Pecs 1984) was the first man in the professorship of Pedagogy between 1966 and 1970.

1944/45., the war year directly affecting Debrecen, caused disturbance in the continuity of the work. Sandor Karacsony, who resided in Budapest, was substituted. However, later on it was him who was asked to notice lectures on Philosophy. 1949/50 created a vacuum, after the removal of Sandor Karacsony the position of the professorship was vacant for a while, but practically the professorship as a structural unit did not function either. We can only state an administrative continuity. The proportions were hard to reconstruct but they were not resulting only from the lack of a head teacher but from the period on the whole. The 'university reform' of 1949 created a deranged situation for the pedagogical subjects and teacher training. Pedagogical and other kinds of lectures, subjects and exams were made obligatory without having teachers to them. The situation was similar in more other departments where the new authority removed professors entitled 'reactionist'.

There were more names included in the student offices until the commission of Bela Jausz as head of the department. Teaching work was going on but the department itself was not in operation. There were only few left from the lecturers at the university. Some of them counted notable later in the profession but some of them proved to be only temporary characters.

Due to the 1949's rules the structural unit was significantly altered. The earlier structural order had the department as a unit few in number with a professor and an assistant, maybe a trainee. The lectures were noticed by the university professors and they were the ones to certify the exams as well. Private teachers with habilitation could also be present with restricted right to examinations and their lesser paid courses. This scheme was altered by a multiple-stage hierarchic system in the socialist period. The steps of the 'ladder' meant the following statuses still known today: assistant lecturer, senior lecturer, associate professor and professor. The university of the new political system brought more departments in number so did the number of students. The educating tasks moved towards the lower positions of the service ladder. Affairs regarding decision and responsibility had changed. By the end of our examined period 
the manpower of the department of Pedagogy had reached 15 people. The new structure had become integrated (Vasko, 1981).

The naming of the structural unit connected to the professorship has its own history as well. The change of the names can be results of the professional orientation of the professor or that of the structural alteration of the university. From 1949/50 the names Seminary of Pedagogy and Institution of Social Psychology ceased to exist and its place was given to the Institution of Pedagogy which is one of the eight institution of the Arts Faculty at the time. The new structural change taking place in 1970 divides the institution of pedagogy into three parts: Departments of Pedagogy, Psychology and Andragogy, which constituted a common group of department with Professor Laszlo Kelemen as the head.

\section{The Professional, Spiritual Continuity}

Nowadays it seems evident again that all professors (head of department, the owner, leader of the professorship) would like to start his department's teaching and researching work with his own program. He would like to draw a clean slate to an extent, even if he takes the professorship as a student of his forerunner. In the examined period and professional field, it was not always required to be committed to the antecedents. Especially not after the change of system after the war.

If we can talk about a civilian and socialist period in the investigated decades from the founding of the university, then it was in the civilian period when the continuity of teacher-student could be more likely, however, the (narrowly taken) attitudinal continuity. It is well known fact that, Sandor Karacsony could not continue the Mitrovics-style aesthetic and psychological line of conduct, he represented his own social psychological line in his lectures and publications. Though, this can be explained with the difference in their personal and professional conviction.

On the contrary, the discontinuity between the civilian and socialist courses is spectacular: it can be observed in operational pauses and declarations as well. In an ideologized professionalism (avowable) continuity is not bearable. From the 50's until the investigated period the representation of professional line of conduct did not count only as a question of scientific conviction. Only in the measure and the nature of cooperation or keeping of distance can interpretable differences be searched. Therefore, professional and spiritual continuity is to be raised differently in the civilian and the socialist periods.

In the first, the teacher as an applicant was invited and accepted with his principles knowingly and respectively. Before his appointment his program and work in his application were considered and the differences between applicants were accounted for that. Mainly this practice prevailed even if we know that there were less public reasons 
for a decision, a commission. In the case of Mitrovics and Karacsony we know a lot of details and thoughts about this progress (Vincze, 2011).

In the socialist period, teachers were instructed to represent and teach the official line of conduct. Their work was regarded as a contribution to the line of the 'brunt'. This period needs to be examined by being conscious and considerate of the foregoing. At the same time, not only executor roles could be undertaken. A teacher or leader could achieve recognition and professional freedom inside the elbow-room of the system. For example, Bela Jausz got his professorship being a recognized head of a school, he was treated as one belonging to Debrecen and he had his own personal respect as well. His career did not launch in the socialist paradigm and as far as we know he was not politically committed either. Laszlo Kelemen was a successful researcher when he was invited to the department only his religiousness was stressed behind his back. He got the vacant position caused by retirement of the professorship coming as a professional from the fields of psychology and school researches. The change in the head caused a change in the professional line of conduct in the before mentioned frames and areas.

Our research could only get to the setting of the hypotheses for the question of the professional continuity of the whole period. There are more set of values that assumes and accompanies continuity: the identity of the protestant spiritualism, being from Debrecen or that of commitment to a pedagogical paradigm. So far, Tamas Kozma (2007) assumes two professional lines of conduct going through the examined period: the Mitrovicsian philosophical-psychological and the Karacsonyian free-education trends. He declares these two as they were arcing over the alterations of political courses, mainly hidden or half publicly, but they can be recognized today in the teachings and effects of the professorship of Pedagogy in Debrecen.

The investigation of the professional and spiritual continuity is a hard task for a researcher in more aspects. It is hard, as it is strongly attached to people and attitudes: it presumes the collective monitoring of works, messages and relationships. It is acutely difficult as the professional profile of the professorship was basically not formed by the professional-immanent convictions but the ideological and political orders. The altered structure of the department made the determining role of the professor grow dim. It was so outwardly and inwardly as well. The power relations of the department and institution, the raised number and more times hierarchized staff had made peculiar dependencies. Regarding the tasks and structural features of the university and the department of the socialist era were substantially different from those of the civilian period. It worked in order with more people in number, according to a hierarchy and was supported and controlled by the partners of the system in the staff, the trade union and the party. In this field of power the professional head could carry out his own restricted decisions.

This is where - in our opinion - the problem of researching the continuity of the structure, professorship and spiritualism meet. More accurately, this circumstance gives 
the must of handling of the professional and spiritual face of the department differently from the 50's. A period of a certain professorship did not mean a uniform aspect tied to the researches and disciplinary creed of a professional leader or not in every case of the departments. The professional profiles and relationship systems of teachers, first of all the associate professors had the representation of the professorship pluralized and became pluralized. In such an articulated relationship, requirements regarding teaching and scientific life prevailed peculiarly.

Above all of the foregoing, professional continuity has an emancipatory thread, which can be followed throughout: preservation of professionalism in the university and the work for the prestige of pedagogical science. In a natural way, with different tools, colours and tone, Mitrovics, Karacsony, Jausz, Kelemen and we can risk that all the others following them undertook the representation of this matter. Let's add, they had varying degrees of success.

First of all, Gyula Mitrovics's aesthetic and psychological work is what helping the university accept his pedagogy, too. However, the opinion of his successor is prevailing, namely, that Mitrovics can only be regarded consequentially as a true scientist of pedagogy. On the contrary, Sandor Karacsony had to cope with the opinion and represent the profession, that although his lectures are very popular, it is thanks to his popular way of diction, rather than its scientific content. His fellow professors argued with his order of his views and scientific validity. Bela Jausz started out in German Studies. He was acknowledged for his work in organizing the training grammar school and its working successfully. His accomplishments in professional science met with less warm response. Though, it is true that his professorship was at the time of the spiritually altered period. For Laszlo Kelemen, establishing and summarizing the pedagogical psychology inland meant the basis for the personal and professional acknowledgement and acceptance. He met much opposition as a head of the department and the institution and also as a vice-rector as well, he had difficulties in representing the matters of pedagogy and teacher training.

There are also differences in the intellectual heritage of the professors. Mitrovics spent his time of retirement in Germany. The national profession 'forgot' him for a long time and was silent regarding his work. We can find an analytical read about him only in the 90's and there was a thesis for the doctor's degree (Vincze, 2011) in the framework of the mentioned research. Sandor Karacsony had another story, he was bumped by the new authority and after his death and he was only mentioned critically in the professional literature. His professional and personal rehabilitation started in the 80's. Bela Jausz took a professional-public role as the head of the Hungarian Pedagogical Society in his pensioner years. The university honoured him with a Memorandum Album (Emlekkonyv, 1976). There was a thesis for the doctor's degree about his career and work (V. Nagy Aniko, 2009; 2013). The heritage and work of Laszlo Kelemen has not been processed. 
In our study we are summarizing some of the conclusions of our research, which characterized 50 years of the pedagogical professorship in the University of Debrecen with regard to its structural and personal changes. The period of four school-funding professors had their time intercepted by socio-political shifts that affected the destiny of the professorship and the people and had a great influence on the situation and spirit of the discipline in the university.

\section{References}

Bajko, M. (1976, Eed.). Jausz Bela emlekkotet. Debrecen: Magyar Pedagogiai Tarsasag.

Brezsnyanszky, Laszlo (2007, Ed.). A „Debreceni Iskola” nevelestudomany-torteneti vazlata (p. 424). Budapest: Gondolat.

Kozma, Tamas (2007). Hasonlosagok es kulonbsegek a debreceni iskola pedagogiajaban. In: Brezsnyanszky, Laszlo (Ed.). A „Debreceni Iskola” nevelestudomany-torteneti vazlata (pp. 399416). Budapest: Gondolat Kiado.

Mitter, Wolfgang (2003). Transzformaciok az europai oktatasugyben kulonos tekintettel az újraegyesített Nemetorszagra. Magyar Pedagogia, 103. evf.(4.), 413-421.

Nemeth, Andras (2016). Die historische Pädagogik in Ungarn. Geschichte und heutiger Stand. The History of Education looking at itself. Espacio, Tiempo y Education, Vol 3, (No.1.), 85-110.

Orosz, Istvan - Barta, Janos (2012, Eds.). A Debreceni Egyetem tortenete 1912-2012. Debrecen: Debreceni Egyetemi Kiado (Debrecen University Press).

Papp, Klara (2014, Ed.). A Debreceni Egyetem Bolcseszettudomanyi Karanak tortenete I. Debrecen: Debreceni Egyetem Bolcseszettudomanyi Kar.

Varga Zoltan (1967). A Debreceni Tudomanyegyetem tortenete (1944-ig). Debrecen.

Vargane Nagy Aniko (2013). Jausz Bela a pedagogus professzor. Az 1919-1959 kozotti szakmai eletút elemzese. PhD dissertation, manuscript.

Vasko Laszlo (1980). Adatok a tanszek fejlodestortenetehez (1944-1970). In: Bajko, L., Vasko, L., Petrikas, A. (Eds.). Vazlatok es tapasztalatok a pedagogiaoktatas es a nevelestudomanyi tanszek tortenetebol (pp. 18-47). Debrecen.

Vincze Tamas (2007). Mitrovics Gyula „muhelye” a Debreceni Egyetemen. In: Brezsnyanszky Laszlo (Ed.). A „Debreceni Iskola” nevelestudomany-torteneti vazlata (pp. 118-127). Budapest: Gondolat Kiado.

Vincze Tamas (2011). Karrierutak es iskolateremtes a XX. szazad elso felenek magyar nevelestudomanyaban. PhD dissertation, manuscript. 